\title{
Narrating the South Pacific in and Beyond Great Power Politics
}

\author{
Chengxin $\operatorname{Pan}^{1}$ D $\cdot$ Matthew Clarke $^{2}$
}

Received: 14 December 2021 / Accepted: 15 December 2021 / Published online: 30 January 2022

(C) The Author(s), under exclusive licence to Springer Nature B.V. 2021

\begin{abstract}
Once considered a bunch of "small islands in a far sea" by outside powers, the South Pacific now looms increasingly large on the global geopolitical landscape, attracting the strategic attention of an array of great powers. This has prompted many scholars and commentators to focus on the rise of great power rivalry in the region. Yet, with few exceptions, the existing literature has paid little attention to how the regional dynamics are framed by the dominant narrative of great power politics in the first place and how as a result it has failed to adequately consider alternative voices, concerns and narratives from within the region. This Special Issue aims to tentatively address this neglect by questioning the unreflective narration of regional power dynamics as mere "great power politics" and by highlighting the competing narratives about this region and their policy implications for conducting relations between the South Pacific and "outside powers". In doing so, it seeks to provide a new critical and self-reflective angle for the debate on the South Pacific. This article first examines the extent to which "great power politics" reflects the reality of the power dynamics in the South Pacific. It then explains why it is important to focus on the theme of narratives and to understand their socially constitutive role in producing knowledge and shaping reality. The third section briefly introduces the five articles in this Issue and outlines their contributions.
\end{abstract}

Keywords The South Pacific · Great power politics · Narrative $\cdot$ China's rise · Everyday knowledge production

Chengxin Pan

cxpan@um.edu.mo

Matthew Clarke

matthew.clarke@deakin.edu.au

1 The University of Macau, Macao, China

2 Deakin University, Melbourne, Australia 


\section{Great Power Politics in the South Pacific: Reality and Narrative}

Often considered merely a bunch of "small islands in a far sea" [27, p. 153], the South Pacific now looms increasingly large on the global geopolitical landscape. But the newfound interest in the region has more to do with "great power politics" than with the well-being and future of this region per se. As a "European artefact", the "South Pacific" was from the outset intertwined with imperial rivalry and geopolitical competition, as evidenced in the scramble for Pacific colonies in the late nineteenth and early twentieth centuries and the Pacific War of the 1940s [20, p. 180; 45]. During the Cold War, it was seen by both Australia and the USA as critical to their access to security partners as well as trade routes [13, 22]. As the Cold War ended, the South Pacific receded into a geoeconomic and geopolitical "backwater" as far as Western powers were concerned. It remained the case even when East Asian economic dynamism and growing trade and investment opportunities across the Pacific Ocean heralded the dawn of the "Pacific Rim" (and later "Asia-Pacific") 1 as a promising integrated geoeconomic unit in the post-Cold War era. If anything, the South Pacific was often dismissed as (part of) an "arc of instability" [15, p. 18; $7 ; 17]$, something of an anomalous distraction to an otherwise economically vibrant Asia-Pacific community.

For the past decade or so, the liberal optimism of Asia-Pacific regional integration [55] has been noticeably replaced by a sense of "Indo-Pacific" realpolitik fear and anxiety over the rise of China [50]. Like its elevated importance during the Cold War period, today, the South Pacific is once again thrust into the geostrategic limelight, becoming the focal point of a raft of newly announced policies by countries as diverse as Britain ("Pacific Uplift"), Indonesia ("Pacific Elevation"), New Zealand ("Pacific Reset") and Australia ("Pacific Step-up"). Furthermore, the South Pacific is not only included in China's "Belt and Road Initiative" [10, 51], but it also forms "an essential part" of the US's "free and open Indo-Pacific region" [63]. Never before has the South Pacific been so strategically attractive to so many powerful players.

As the region seems to be well and truly caught in the middle of a broader game of great power competition, it has also attracted increasing scholarly attention in the field of International Relations (IR) [11, 12, 25, 26, 30, 38, 54, 59, 65, 68]. The burgeoning literature has examined many important questions, such as whether China will become a hegemon in the region, whether Beijing's Pacific policy is driven primarily by geopolitical or commercial imperatives, whether US-China relations in the Pacific are best characterized as a new Cold War-if so who is winning the new Cold War-and what implications China's presence and intensifying great power competition may have for the region and its traditional hegemonic power Australia.

\footnotetext{
1 Arif Dirlik [16, p. 135] argues that "Discussions of the Pacific Rim... rarely account for all the societies thus situated, more often than not referring primarily to societies of the northern hemisphere and sometimes using the term euphemistically as a contemporary substitute for what used to be called East Asia".
} 
While these questions are clearly worth pondering, the dominant focus on these largely empirical issues has neglected a no less important aspect of international relations of this region, namely, how the regional dynamics are framed and narrated in the first place. With few exceptions [e.g., 21, 51], the majority of the existing literature on the South Pacific largely bypasses this question. Treating great power rivalry and China's growing influence in the region as a matter of fact, it proceeds to debate about the empirical details of such "facts". In doing so, it willingly or unwittingly assumes and indeed reinforces particular ways of framing the region as the regional reality per se.

We believe that this dominant assumption in the existing literature needs to be questioned. For all its empirical richness and apparent analytical objectivity, the existing literature has been heavily influenced by a dominant narrative of great power politics when it comes to understanding the South Pacific. Of course, we do not claim that there does not exist great power politics at all or that it is merely a discursive construct. Rather, we argue that great power competition, real as it is, cannot be separated from the "great power politics" narrative that continuously serves to breathe this "reality" into life. What is problematic is that by adopting a greatpower-centric perspective, this narrative not only contributes to its materialization in practice, but also limits the study of the region to a rather narrow perspective of geopolitics and/or geoeconomics, at the expense of other perspectives and interpretive frameworks.

While such dominant narratives help construct reality, they are never value-free or politically neutral. For example, the familiar and seemingly harmless reference to the South Pacific as "small islands in a far sea" mentioned at the beginning of this article is not just a truthful descriptive statement, but paints countries in the South Pacific as weak and passive actors lacking their own agency or voice, so much so that the region is routinely described as a strategic void or vacuum, hence a vulnerable playground of great power politics [51]. As a consequence, IR scholars rarely study this region on its own merit, and often place its importance in the strategic context of great power rivalry between China and the USA (and its allies such as Australia), as if the region becomes relevant only because China's presence here seems to pose a challenge to the interests of other great powers $[18,29,30,38,44$, $59,60,68,70,71]$. Such great-power-centric analysis, diverse and insightful as it is, is often further situated within a broader narrative web of IR, made up of such familiar concepts as "power shift", "Thucydides Trap", "debt trap", the "China threat" and the "Indo-Pacific" [5, 9, 14, 28, 40, 43, 48-50].

By now, it becomes clearer that narratives are not marginal but central to IR in general and the study of the South Pacific in particular. Even with the best of efforts, they are not something scholars and commentators can easily avoid. Despite or precisely because of this, it is possible and indeed necessary to more explicitly engage with them in a more critical and self-reflective fashion. It is against this background that we believe it is now time to take stock of some of the prevailing ways of narrating the South Pacific by examining for example whether the great-power-centric narratives can adequately reflect the new and complex power dynamics in the South Pacific; whether foreign policy towards the region, often informed by those dominant narratives, has achieved its goals; what local voices and alternative narratives 
have been marginalized; and how such marginalized narratives could provide new lenses through which to understand this important region in its own terms. Hence, the theme of this Special Issue: narrating the South Pacific in and beyond great power politics. By addressing some of those above-mentioned questions, this Issue aims to provide a new critical and self-reflective angle for the debate on the South Pacific. Before turning to a brief outline of individual articles in this Issue, we now explain what we mean by "narrative" and why a focus on the role of narrative is necessary.

\section{Narrative, Social Reality and Policy Practice}

Narrative is a "ubiquitous" "semiotic phenomenon that transcends disciplines and media" [Marie-Laure Ryan, quoted in 32, pp. 72-73]. Initially referring to a particular literary genre, this concept has now been associated with a number of fields in the humanities and social sciences [32, pp. 72-73]. IR is no exception and its importance in the construction of world reality has attracted increasing research interest [e.g., 19, 23, 33, 42, 47]. While some treat narrative as a particular subset of discourse which centres on story-telling and is organized through a clear sequential order [see 24], we prefer a looser conception of narrative, defined as a particular, often influential and easily memorable, way of both interpreting and organizing reality, with an often distinctive and succinct form of linguistic expression, although narratives can also be expressed in non-linguistic forms [see for example 6]. Though always having certain story-telling functions, narrative can take the diverse forms of media memes, political catchphrases, conceptual framings, theoretical formulations and so forth [34, 36].

This definition allows us to better capture the intertextual relations among otherwise separate and seemingly non-story-telling concepts such as "sphere of influence", "arc of instability" and "great power rivalry". 2 Through intertextual linkages and interactions, they together can tell a story that conveys particular political meanings and serves particular interests. This is perhaps how when it comes to narrating the South Pacific, "paradise", "noble savages", "sphere of influence", "great power rivalry", "arc of instability", the "Pacific family" and the "Indo-Pacific" are able to speak to one another, allowing people to construct a more or less coherent story about this region.

This socially constitutive role of narrative is particularly relevant to the reason why we turn to narrative in the analysis of the South Pacific. If narrative was just a transparent medium through which we capture objective reality out there, then certainly focusing on narrative, instead of "reality" itself, would seem pointless. But the neat distinction between "reality" and "narrative" is misleading. Hayden White for example rejects the mistaken view of narrative as "a neutral 'container' of historical fact, a mode of discourse "naturally' suited to representing historical events directly"

\footnotetext{
${ }^{2}$ In fact, as building blocs of texts, all concepts have an intertextual history in which they are linked to other texts and larger narrative ecosystems. On the concept of intertextuality, see [3, 39].
} 
[67, p. 37]. "Narrative", he argues, "is not merely a neutral discursive form ... but rather entails ontological and epistemic choices with distinct ideological and even specifically political implications" [66, p. ix]. Consequently, whether it is historical events or contemporary world politics, reality does not precede narrative, nor is narrative a passive, after-the-fact response to such reality. Our understanding of reality is from the beginning mediated through narrative. Thus, we need to de-naturalize "reality", such as the "reality of great power politics" in the South Pacific, which can be best understood in conjunction with a study of the constitutive effect of the "great power politics" narrative. Even scholars who claim to focus only on "objective fact" nevertheless rely extensively on narratives and discourses already created for them.

Of course, social reality cannot be simply reduced to or relativized by any ideas or narratives, and certainly narratives are not all that is in the world. ${ }^{3}$ For instance, the scourge of the COVID-19 could not be simply narrated away. Nevertheless, how the pandemic is narrated, particularly by the most powerful, does affect social behaviour and practice, which in turn contributes to different social outcomes. Thus, it is safe to say that dominant ideas and narratives help construct the world we live in and study. By asking whose narratives are behind the prevailing constitution of reality and whose narratives are excluded or marginalized [35, p. 121], narrative analysis is not an escape from "real-world" problems, but central to understanding the (unequal) power relations in the social construction of reality and how the real world is made and may be remade.

While there has been a growing body of literature that focuses on strategic narrative in general and its relevance to understanding international relations in places such as China, Europe, East Asia and the Indo-Pacific [4, 8, 24, 33, 41, 46, 57, 58, 62, 69], studies on international relations narratives concerning the South Pacific are still relatively rare [with exceptions such as 21,64 ]. To some extent, this Special Issue aims to fill this gap.

In doing so, we also see this endeavour as a small contribution to the quest for Global IR, which advocates for "advancing IR toward a more inclusive and universal discipline" [2, p. 5]. To this end, IR "must offer concepts and theories that are derived from other societies and cultures" [2, p. 6]. This Special Issue shares the concern about the continued dominance of Western theoretical and conceptual understandings of a primarily "non-Western" region and its international relations. However, it believes that challenging Western-centric knowledge production in IR requires critically interrogating not only formal Western IR concepts and theories such as realism and liberalism, but also ubiquitous and seemingly commonsensical narratives. After all, IR theories are themselves "ensembles of contesting narratives about the nature of global relations" [47, p. 137], and most of us are first and foremost not a theorist, or even a scholar, but a story-teller living in the web of narratives spun by us and others. As Jean-Paul Sartre puts it, a person "is always a story-teller, he [sic] lives surrounded by his stories and the stories of others, he sees everything that happens to him through them" [quoted in 56, p. 452]. Therefore, in

\footnotetext{
3 There are different levels of commitment to the role of meaning and idea in the social construction of reality, ranging from conventional constructivism through critical theory to poststructuralism.
} 
the pyramid of knowledge production in IR, narratives and narrators are more common than theories and theorists, and the Western-centrism of IR theories cannot be detached from the Western-centrism of IR narratives which have been drawn largely from European historical experiences [37, 52].

While this Special Issue does not claim to contribute to Global IR theorizing per se, questioning dominant narratives about a non-Western region and highlighting alternative narratives do help contribute to diversifying and globalizing the production of IR knowledge in general. If the recent "Global IR" or "post-Western IR" literature has focused on decentring Western IR theories and promoting geographically diverse IR theory constructions [1, 2, 31, 61, 72], this Special Issue represents a much more modest yet no less worthwhile effort to highlight the unequal relationship in everyday knowledge production in IR when it comes to representing and narrating a "non-Western" region.

\section{Contributions of the Special Issue}

This Special Issue collectively makes two broad contributions. First, it sheds light on some dominant narratives in relation to the South Pacific, such as "great power politics" and the "Indo-Pacific", and critically interrogates their historical origins and/or policy consequences. In this context, the Special Issue focuses on Australia's and China's narratives and policies, and to a lesser extent, those of France's and the US's. With their longstanding connections with the region and their prominent role in the emerging power dynamics in the South Pacific, these countries' renewed policies and engagements with the region are arguably most consequential. Through historical and comparative analysis as well as case studies, several contributions demonstrate both the links and divergence between dominant narratives and their constitutive effect on policy practices.

Second, the Issue draws much-needed attention to some alternative narratives in and about the region, and examines how such alternative narratives can better contribute to our understanding of this important region. It illustrates that though often at the receiving end of dominant narrative framings in international politics, the South Pacific is not a passive object of social construction initiated by great powers. Rather, it is able to articulate its own diverse and different interests through alternative narratives about itself and the wider world. The "large ocean states" and "Blue Pacific" narratives are cases in point. Articulating a different vision of their own region, Pacific Island leaders demonstrate the will and agency to pursue collective diplomacy in the face of challenges like climate change, ocean management and now COVID-19. In this sense, despite or precisely because of the dominance of conventional "great power politics" narratives, it is necessary to engage with such marginalized voices and narratives expressed from within the region, and to understand how they play an important role in the complex regional power dynamics. For this reason, the Special Issue calls for understanding the region on its own terms, and paying closer attention to voices, perspectives and concerns from within the South Pacific. 
In addition to these largely shared objectives, the five articles in the Special Issue naturally have their own focuses, empirical emphases and diverse arguments. In his contribution to the collection, Stephen Ratuva notes that a common feature of the geopolitical contestation in the Pacific is the weaponization of the "China threat" imagery, or what he calls the "Sinophobic narratives" in the USA, France and Australia, three of the most dominant Western powers in the region. These narratives can be traced back to their deeper racial and historical genesis, namely, the largely racial framing in the historical notion of the "yellow peril". He argues that these traditional powers have invoked the subconscious cultural and racial prejudice in international politics associated with their Sinophobic narratives in an attempt to de-legitimize China's expansion into the Pacific. Ratuva's contribution helps connect contemporary geopolitical rivalry with a deep-seated historical narrative that remains relevant and active today.

Contrasting the China-threat discourses in the prevailing security narratives, Sandra Tarte's article introduces a different narrative on regional security, the "Blue Pacific", which focuses on human security and climate change. While noting these divergent ways of narrating the region, Tarte argues that it is nevertheless possible to explore areas of convergence in these regional security narratives. Drawing on past instances of security cooperation, such as the South Pacific Nuclear Free Zone of 1985 and the Regional Assistance Mission to Solomon Islands (RAMSI) from 2003 to 2017, her article illustrates that all is not lost in the competing discourses among great powers and that a new Pacific diplomacy may empower Pacific Island countries to advance their own security priorities within a more cooperative security framework.

While Tarte is cautiously optimistic about the prospect for security cooperation, both Wesley Morgan and Michael O'Keefe, in their respective articles, express doubt about Australia's ability to come to terms with the priorities and dynamisms of Pacific regionalism. Surveying the Pacific's longstanding images and narratives about cultural and economic connections with the ocean, Morgan highlights the region's narratives about itself in terms of "large ocean states" and the "Blue Pacific". The articulation of these identities stands in contrast to Australia's continued discourses of the region as "small, isolated and fragile", which is believed to be vulnerable to pressures of outside influence, notably from China. He argues that, driven by a unilateral strategy to deny the islands to other powers such as China, Australia's "Step Up" strategy, underpinned by its "Indo-Pacific" narrative, largely prioritizes its own security interest. If it is to succeed, Canberra needs to take the region's narratives more seriously and to engage more closely with the security concerns of the Blue Pacific.

In his contribution, O'Keefe engages with a fascinating case study of Australia's policy in the Pacific, notably its "smart" sanctions against Fiji. Motivated by Australia's longstanding regional leadership aspirations and its pursuit of "strategic denial" against unwelcome outside competition, the policy of "smart" sanctions ironically contributed to the very consequences of such competition it purported to prevent. That is, it helped drive Fiji's "Look North" policy and create the opportunity for China (and other powers) to develop closer ties with the region, contrary to the original goal of denying China's influence. This study shows not only 
the limitations of sanctions as a foreign policy tool in dealing with countries in the South Pacific, but also the imperative to be more receptive to the dynamics of "New Pacific Diplomacy".

The final article in this Special Issue looks at China's growing engagement with Pacific Island countries, a key development that has widely been seen as responsible for the intensified geopolitical rivalry. In this article, Yu Lei and Sophia Sui examine how China's increasing strategic influence in the region has resulted from its multifaceted approaches, which include providing economic assistance, pursuing its traditional strategy of non-interference and extending its economic and political involvement. While not without pitfalls, they argue that China's approaches have in part been based on its willingness to engage with the region on the latter's own terms as well as China's strategic calculations.

From the analyses of these articles, it is clear that like it or not, great power politics has been in full swing, and so it is already part of the regional reality. And yet, given the dangers and negative consequences of pursuing great power competition, one of the biggest questions facing the region is whether collectively all relevant players can rise above this self-fulfilling game and mitigate the potentially devastating impact of such competition. There are likely to be different answers to this pressing question, but as several articles in this Issue will illustrate, a good starting point is to listen more attentively to the region's own aspirations, concerns and priorities. If this message begins to be heeded by countries such as Australia and China, then perhaps their engagement in the region could provide opportunities for multilateral cooperation as well as healthy competition.

Funding The authors received funding support from Alfred Deakin Institute for Citizenship and Globalisation at Deakin University for the workshop "Power Dynamics in the South Pacific: Development, Governance and Peace in Australia's Near Neighbourhood” held at Deakin University in November 2019.

\section{Declarations}

Conflict of Interest The authors declare no competing interests.

\section{References}

1. Acharya, A. and Buzan, B. eds. (2010). Non-Western International Relations Theory: Perspectives On and Beyond Asia. London: Routledge.

2. Acharya, A. (2016). Advancing global IR: Challenges, contentions, and contributions. International Studies Review, 18(1), 4-15.

3. Bakhtin, M. (1986). Speech Genres and Other Late Essays. Austin, TX: University of Texas Press.

4. Barthwal-Datta, M. and Chacko, P. (2020). The politics of strategic narratives of regional order in the Indo-Pacific: Free, open, prosperous, inclusive? Australian Journal of International Affairs, 74(3), 244-263.

5. Beeson, M. and Wilson, J. (2018). The Indo-Pacific: Reconceptualizing the Asian regional space. East Asia: An International Quarterly, 35(2), 79-84.

6. Bleiker, R. ed. (2018). Visual Global Politics. London: Routledge.

7. Bradford, R. (2021). Climate security in the South Pacific: Australia's perspective. Land Power Forum (blog), The Australian Army Research Centre, 16 September. Available at: https://researchce 
ntre.army.gov.au/library/land-power-forum/climate-security-south-pacific-australias-perspective (accessed 25 October 2021).

8. Breuer, A. and Johnston, A. I. (2019). Memes, narratives and the emergent US-China security dilemma. Cambridge Review of International Affairs, 32(4), 429-455.

9. Chacko, P. ed. (2016). New Regional Geopolitics in the Indo-Pacific: Drivers, Dynamics and Consequences. London: Routledge.

10. Chen, J. (2015). "Belt and Road" Takes New Route. China Daily, April 15, available at https:// www.chinadaily.com.cn/bizchina/2015-04/15/content_20435585.htm (accessed 5 June 2021).

11. Clarke, M. and Feeny, S. (2019). The dragon versus the kangaroo: Perceptions of Chinese and Australian influence and development assistance in Vanuatu. Australian Journal of Political Science, 54(3), 334-354.

12. Connolly, P. J. (2016). Engaging China's new foreign policy in the South Pacific. Australian Journal of International Affairs, 70(5), 484-505.

13. Dalby, S. (1993). The "Kiwi disease": Geopolitical discourse in Aotearoa/New Zealand and the South Pacific. Political Geography, 12(5), 437-456.

14. Davis, S., Munger, L. A., and Legacy, H. J. (2020). Someone else's chain, someone else's road: U.S. military strategy, China's Belt and Road Initiative, and island agency in the Pacific. Island Studies Journal, 15(2), 13-36.

15. Dibb, P., Hale, D. D., and Pince, P. (1999). Asia's insecurity. Survival, 41(3), 5-20.

16. Dirlik, A. (1995). What's in a Rim? Peace Review, 7(2), 135-141.

17. Dobell, G. (2007a). The arc of instability: History of an idea, in R. Huisken and M. Thatcher eds., History as Policy: Framing the Debate on the Future of Australia's Defence Policy. Canberra: ANU E-Press, pp. 85-104.

18. Dobell, G. (2007b). China and Taiwan in the South Pacific: Diplomatic chess versus Pacific political rugby (Policy Brief), Sydney: Lowy Institute for International Policy.

19. Edkins, J. (2013). Novel writing in International Relations: Openings for a creative practice. Security Dialogue, 44(4), 281-297.

20. Fry, G. (1997). The South Pacific experiment: Reflections on the origins of regional identity. The Journal of Pacific History, 32(2), 180-202.

21. Fry, G. (2019). Framing the Islands: Power and Diplomatic Agency in Pacific Regionalism. Canberra: ANU Press.

22. Gale, J. B. (2019). Competition and cooperation in the South Pacific. The National Bureau of Asian Research, 15 August 2019. Available at: https://www.nbr.org/publication/competition-and-coope ration-in-the-south-pacific/ (accessed 5 July 2021)

23. George, J. (1994). Discourses of International Relations: A Critical (Re)Introduction to International Relations. Boulder, CO: Lynne Rienner.

24. Hagström, L. and Gustafsson, K. (2019). Narrative power: How storytelling shapes East Asian international politics. Cambridge Review of International Affairs, 32(4), 387-406.

25. Hameiri, S. (2015). China's "charm offensive" in the Pacific and Australia's regional order. The Pacific Review, 28(5), 1-24.

26. Hannan, K. and Firth, S. (2015). Trading with the dragon: Chinese trade, investment and development assistance in the Pacific Islands. Journal of Contemporary China, 24(95), 865-882.

27. Hau'ofa, E. (1994). Our sea of islands. The Contemporary Pacific, 6(1), 148-61.

28. Hayward-Jones, J. (2013). Big Enough for All of Us: Geo-Strategic Competition in the Pacific Islands. Sydney: Lowy Institute for International Policy, available at: https://www.lowyinstitute. org/publications/big-enough-all-us-geostrategic-competition-pacific-islands (accessed 10 November 2020).

29. Henderson, J. and Reilly, B. (2003). Dragon in paradise: China's rising star in Oceania. The National Interest, No. 72, 94-104.

30. Herr, R. (2019). Chinese Influence in the Pacific Islands: The Yin and Yang of Soft Power. Barton: Australian Strategic Policy Institute.

31. Hurrell, A. (2016). Beyond critique: How to study global IR? International Studies Review, 18(1), 149-151.

32. Hyvärinen, M. (2010). Revisiting the narrative turns. Life Writing, 7(1), 69-82.

33. Inayatullah, N. and Dauphinee, E. eds. (2016). Narrative Global Politics: Theory, History and the Personal in International Relations. London: Routledge.

34. Jerdén, B. (2014). The assertive China narrative: Why it is wrong and how so many still bought into it. Chinese Journal of International Politics, 7(1), 47-88. 
35. Joenniemi, P. (2008). Russia's narrative resources. Journal of International Relations and Development, 11(2), 121-127.

36. Johnston, A. I. (2013). How new and assertive is China's new assertiveness? International Security, 34(4), 7-48.

37. Kang, D. C. and Lin, A. Y-T. (2019). US bias in the study of Asian security: Using Europe to study Asia. Journal of Global Security Studies, 4(3), 393-401.

38. Köllner, P. (2020). Australia and New Zealand face up to China in the South Pacific, GIGA Focus, no. 3, pp. 1-13. Available at: https://nbn-resolving.org/urn:nbn:de:0168-ssoar-68331-7. Accessed 15 May 2021.

39. Kristeva, J. (1986). Word, dialogue and novel, in Toril Moi ed., The Kristeva Reader. Oxford: Blackwell, pp. 34-61.

40. Lanteigne, M. (2012). Water dragon? China, power shifts and soft balancing in the South Pacific. Political Science, 64(1), 21-38.

41. Ling, L.H.M. and Nakamura, M. (2019). Popular culture and politics: Re-narrating the Senkaku/ Diaoyu islands dispute. Cambridge Review of International Affairs, 32(4), 541-558.

42. Linklater, A. (2009). Grand narratives and international relations. Global Change, Peace \& Security, 21(1), 3-7.

43. Medcalf, R. (2012). The Indo-Pacific: What's in a name? The American Interest, 9(2), 58-66.

44. Medcalf, R. (2020). Contest for the Indo-Pacific: Why China Won't Map the Future. Melbourne: La Trobe University Press.

45. Megaw, M. R. (1977). The scramble for the Pacific: Anglo-United States rivalry in the 1930s. Australian Historical Studies, 17(69), 458-473.

46. Miskimmon, A., O'Loughlin, B., and Roselle, L. (2017). Forging the World: Strategic Narratives and International Relations. Ann Arbor: University of Michigan Press.

47. Moulin, C. (2016). Narrative, in A. Ní Mhurchú and R. Shindo eds., Critical Imaginations in International Relations. London: Routledge, pp. 136-52.

48. Pan, C. (2004). The "China threat" in American self-imagination: The discursive construction of Other as power politics. Alternatives, 29(3), 305-331.

49. Pan, C. (2014a). Rethinking Chinese power: A conceptual corrective to the "power shift" narrative. Asian Perspective, 38(3), 387-410.

50. Pan, C. (2014b). The "Indo-Pacific" and geopolitical anxieties about China's rise in the Asian regional order. Australian Journal of International Affairs, 68(4), 453-469.

51. Pan, C., Clarke, M., and Loy-Wilson, S. (2019). Local agency and complex power shifts in the Era of Belt and Road: Perceptions of Chinese aid in the South Pacific'. Journal of Contemporary China, 28(117), 385-399.

52. Pan, C. and Kavalski, E. eds. (2022). China's Rise and Rethinking International Relations Theory. Bristol: Bristol University Press.

53. Powles, M. ed. (2016). China and the Pacific: The View from Oceania. Wellington: Victoria University Press.

54. Ratuva, S. (2014). A new regional Cold War? American and Chinese posturing in the Pacific. Asia \& the Pacific Policy Studies, 1(2), 409-422.

55. Ravenhill, J. (2001). APEC and the Construction of Pacific Rim Regionalism. Cambridge: Cambridge University Press.

56. Ringmar, E. (1996). On the ontological status of the state. European Journal of International Relations, 2(4), 439-466.

57. Roberts, G. (2006). History, theory and the narrative turn in IR. Review of International Studies, 32(4), 703-714.

58. Roselle, L., Miskimmon, A., and O’Loughlin, B. (2014). Strategic narrative: A new means to understand soft power. Media, War \& Conflict, 7(1), 70-84.

59. Schleich, A-M. (2018). Geopolitical trends in the South Pacific: Is the US or China winning? ISPSW Strategy Series: Focus on Defense and International Security, No. 554, pp. 1-10, available at: https://css.ethz.ch/content/dam/ethz/special-interest/gess/cis/center-for-securities-studies/resources/ docs/ISPSW-554\%20Schleich.pdf (accessed 15 July 2020).

60. Shie, T. R. (2010). Rising Chinese influence in the South Pacific: Beijing's Island fever, in A-M. Brady, ed., Looking North, Looking South: China, Taiwan and the South Pacific. Singapore: World Scientific, pp. 137-163.

61. Tickner, A. B. and Wæver, O. eds. (2009). International Relations Scholarship Around the World. London: Routledge. 
62. Turner, O. and Nymalm, N. (2019). Morality and progress: IR narratives on international revisionism and the status quo. Cambridge Review of International Affairs, 32(4), 407-428.

63. US Department of State. (2018). U.S. engagement in the Pacific. September 3, available at: https:// www.state.gov/u-s-engagement-in-the-pacific/ (accessed 5 June 2020).

64. Wallis, J. (2015). The South Pacific: "Arc of instability" or "arc of opportunity"? Global Change, Peace \& Security, 27(1), 39-53.

65. Wesley-Smith, T. (2016). Geopolitics, self-determination, and China's rise in Oceania, in M. Ishihara, E. Hoshino and Y. Fujita eds., Self-determinable Development of Small Islands. New York: Springer, pp. 85-99.

66. White, H. (1987). The Content of the Form: Narrative Discourse and Historical Representation. Baltimore, MD: Johns Hopkins University Press.

67. White, H. (1992). Historical emplotment and the problem of truth, in Saul Friedlander ed., Probing the Limits of Representation: Nazism and the "Final Solution". Cambridge, MA: Harvard University Press, pp. 37-53.

68. Yang, J. (2009). China in the South Pacific: hegemon on the horizon? The Pacific Review, 22(2), $139-158$.

69. Zeng, J. (2017). Does Europe matter? The role of Europe in Chinese narratives of "One Belt One Road" and "New Type of Great Power Relations". Journal of Common Market Studies, 55(5), 1162-1176.

70. Zhang, D. and Lawson, S. (2017). China in Pacific regional politics. The Round Table: The Commonwealth Journal of International Affairs, 106(2), 197-206.

71. Zhang, Y. (2007). China and the emerging regional order in the South Pacific. Australian Journal of International Affairs, 61(3), 367-381.

72. Zhang, Y. and Chang, T-C. eds. (2016). Constructing a Chinese School of International Relations: Ongoing Debates and Sociological Realities. London: Routledge.

Publisher's Note Springer Nature remains neutral with regard to jurisdictional claims in published maps and institutional affiliations. 